\title{
Pembaharuan Kurikulum di Pondok Pesantren Al-Irsyad Islamic Boarding School Bulaan Kamba
}

\author{
Rahimmatul Hayati ${ }^{1}$, Rengga Satria ${ }^{2}$ \\ ${ }^{12}$ Universitas Negeri Padang, Indonesia \\ Corresponding Author, email: renggasatria@fis.unp.ac.id
}

\begin{abstract}
Abstrak
This research aim to find out, explain, and to describe how the renewal of Islamic education in the field of curriculum at al-Isyad Islamic Boarding School Bulaan Kamba, Kubang Putiah (years 2011 until 2021). Including the renewal of the study of yellow book. The location of this research is the Islamic Boarding School al-Irsyad Islamic Boarding School Bulaan Kamba, Kubang Putiah Village, Banuhampu District, Agam Regency. This type of research is a qualitative research with historical research methods. This research was conducted at the Islamic Boarding School al-Irsyad Islamic Boarding School Bulaan Kamba, Kubang Putiah, Banuhampu District, Agam Regency. Data collection techniques were carried out by observation, interviews, and documentation. Data analysis techniques using data reduction, data presentation and data verification. Technique of validating data with triangulation technique. The results of the research conducted by the researchers can be concluded that there is indeed a renewal of Islamic education in the al-Irsyad Islamic Boarding School Bulaan Kamba Islamic Boarding School, Kubang Putiah, especially in the field of curriculum. Renewal is also seen in the study of the yellow book as a source of learning in the daily cottage. The difference between the research that the researcher did and the previous research lies in the object under study.
\end{abstract}

Keywords: Curriculum renewal, yellow book, pesantren

This is an open access article distributed under the Creative Commons 4.0 Attribution License, which permit

unrestricted use, distribution, and reproduction in any medium, provided the original work is properly cited. C2018 by author.

\section{Pendahuluan}

Pesantren merupakan lembaga keagamaan asli Indonesia yang memiliki karakteristik dan nilai-nilai tertentu. Pesantren merupakan lembaga tertua dalam pendidikan Islam di Indonesia yang mengalami perkembangan namun tidak menghilangkan ciri khas pesantren tersebut. Pembaharuan atau modernisasi yang dilakukan oleh pesantern merupakan cara yang dilakukan oleh pesantren untuk tetap dapat bertahan dengan pendirian lembagalembagapendidikan modern yang menawarkan pendidikan sekuler yang sengaja didirikan oleh Belanda. Sebagaimana pendapat Fahrurazi (2016) bahwa pembaharuan dan perubahan dalam pondok pesantren dimaksudkan agar pondok pesantren dapat menyesuaikan diri dan merespons dinamika kehidupan sehingga bisa tetap eksis. Di samping itu, pembaharuan pesantren dapat dijadikan respons untuk menepis penilaian sebagian orang bahwa pesantren lekat dengan penilaian keterbelakangan dan hanya menghasilkan lulusan yang paham fikih atau hukum Islam saja (Fuady, 2020). Sedangkan pendapat Geertz dalam (Anwar, 2011), bertahannya pesantren ditentukan oleh kemampuannya mempertahankan identitasnya sebagai sistem pendidikan yang didominasi oleh kiai dan pada saat yang sama memperjelas perannya sebagai bentuk komplementer pendidikan nasional.

Perubahan perhatian dunia internasional terhadap lembaga pendidikan Islam, terutama madrasah dan pesantren, tidak lepas dari perubahan internal pada institusi pendidikan Islam ini. Menurut Azyumardi Azra, pesantren dan madrasah merupakan salah satu lembaga pendidikan Islam yang mengalami perubahan yang cepat dan luas, setidaknya pada dua dasawarsa terakhir. Perubahan tersebut menyangkut kelembagaan dan substansi keilmuan. Menurutnya, meskipun perubahan tersebut nampaknya merupakan keniscayaan, dampak dan konsekuensinya bagi pendidikan Islam atau bahkan dinamika Islam di Indonesia tidak selalu menggembirakan (Basyit, 2017). 
Pesantren sebagai lembaga pendidikan Islam harus mengadakan perubahan dan pembaharuan. Pembaharuan tersebut berfungsi untuk menghasilkan generasi-generasi yang tangguh bepengetahuan luas dan keteguhan mengembangkan pengetahuan yang bersumber pada Al-Qur'an dan Hadis. Dalam perkembangan zaman, pesantren saat ini berhadapan dengan arus globalisasi dan modernisasi yang ditandai dengan cepatnya perkembangan teknologi. Pesantren harus melakukan perubahan format, bentuk, orientasi dan metode pendidikan ataupun hal-hal lain dengan catatan tidak sampai merubah visi, misi dan orientasi pesantren itu sendiri. Adapun perubahan misi hanya pada sisi luarnya saja, sementara pada sisi dalam masih tetap dipertahankan (Rifai, 2017).

Dilihat dari sejarah berdirinya, sebagai lembaga pendidikan Islam di Minangkabau, pondok pesantren al-Irsyad Islamic Boarding School Bulaan Kamba, Kubang Putiah terus berkembang bersama pondok pesantren terkemuka lainnya, sebut saja pondok pesantren Diniyah Pasia (1928), Madarasah Tarbiyah Islamiyah Canduang (1907), pondok pesantren Sumatera Thawalib Parabek (1910), dan pondok pesantren al-Irsyad Islamic Boarding School Bulaan Kamba (1924). Sampai saat ini, pondok pesantren al-Irsyad Islamic Boarding School Bulaan Kamba masih tetap berdiri dan saat ini sedang dalam masa perkembangannya.

Dilihat dari perkembangan pondok pesantren al-Irsyad Islamic Boarding School Bulaan Kamba mulai dari tahun 1924 sampai tahun 2021, memang banyak terjadi pembaharuan. Namun, pembaharuan yang signifikan tampak terjadi pada sekitar tahun 2011 sampai dengan 2021. Misalnya pada bidang kurikulum yaitu pada materi pembelajaran pondok yang awalnya memakai kitab kuning sebagai panduan dalam pembelajaran, untuk saat ini kitab yang dipakai untuk panduan pembelajaran disesuaikan dengan kurikulum. Oleh karena itu tujuan penelitian ini adalah untuk mengetahui bagaimana pembaharuan pendidikan Islam yang terjadi di pondok pesantren al-Irsyad Islamic Boarding School Bulaan Kamba, Kubang Putiah khususnya dalam bidang kurikulum pada rentang waktu tahun 2011-2021, termasuk pembaharuan pengkajian kitab kuning.

Perbandingan masalah penelitian yang dilakukan dalam penelitian terdahulu dengan penelitian yang peneliti lakukan yaitu pertama, skripsi yang ditulis oleh Rahmat Ramadhan (2017) yang berjudul pembaharuan pendidikan Islam di pondok pesantren al-Muhsin Purwosari, Kota Metro Lampung, permasalahan dalam penelitian ini yang pertama padatnya jadwal kegiatan di pondok pesantren al-Muhsin membuat para santri susah membagi waktu antara tugas pondok dan sekolah sehingga proses pembelajaran kurang maksimal dan permasalahan yang kedua pencapaian nilai akhir santri masih rendah. Kedua, skripsi yang ditulis oleh Adib Muzakky (2020) dengan judul strategi pembaharuan pendidikan Islam di pondok Tarbiyatul Islam al-Falah, Keluruhan Dukuh, Kecamatan Sidomukti, Kota Salatiga. Kedua, skripsi yang ditulis oleh Adib Muzakky (2020) dengan judul strategi pembaharuan pendidikan Islam di pondok Tarbiyatul Islam al-Falah, Keluruhan Dukuh, Kecamatan Sidomukti, Kota Salatiga, permasalahan dalam penelitian ini adalah dalam perkembangan zaman, eksistensi pondok pesantren menjadi terancam, sehingga pondok pesantren melakukan pembaharuan pendidikan Islam dengan berbagai macam strategi yang dilaksanakan dalam berbagai aspek, oleh karena itu peneliti tertarik melakukan penelitian ini. Ketiga, jurnal yang ditulis oleh Rengga Satria (2019) dengan judul pembaharuan pendidikan Islam di Madrasah Tarbiyah Islamiyah Canduang, permasalahan dalam penelitian ini adalah modernisasi atau pembaruan yang terjadi dalam pendidikan Islam di Canduang.

\section{Metode}

Penelitian ini merupakan penelitian di bidang pendidikan Islam yang lebih berfokus kepada aspek sosio-historis pendidikan Islam di pondok pesantren al-Irsyad Islamic Boarding School Bulaan Kamba, Kubang Putiah. Jenis penelitian ini adalah penelitian kualitatif. Penelitian kualitatif adalah penelitian yang berdasarkan pada filsafat pospositivisme, digunakan untuk meneliti pada kondisi obyek yang alamiah, (sebagai lawannya adalah eksperimen) dimana peneliti adalah sebagai instrumen kecil, teknik pengumpulan data dilakukan secara triangulasi (gabungan), analisis data bersifat induktif/kualitatif, dan hasil penelitian kualitatif lebih menekankan makna daripada generalisasi (Sugiyono, 2012). Metode penelitian yang peneliti 
lakukan termasuk dalam metode penelitian historis. Metode penelitian historis bertujuan untuk merekonstruksi kembali secara sistematis, akurat dan objektif kejadian atau peristiwa yang pernah terjadi dimasa lalu (Narbuko \& Achmadi, 2003). Metode pengambilan sampel dalam penelitian ini dipilih secara purposive sampling. Purposive sampling adalah teknik penentuan sampel dengan pertimbangan khusus sehingga layak dijadikan sampel. Maksudnya peneliti memilih informan atau subjek yang dianggap mempunyai pengetahuan terhadap objek yang dipilih. Instrumen penelitian dalam penelitian adalah peneliti sendiri sebagai instrumen penelitian utama. Instrumen penelitian merupakan upaya pengukuran, maka alat ukur dalam penelitian disebut dengan instrumen penelitian. Sehingga instrumen penelitian merupakan piranti mengukur fenomena alam maupun sosial yang menjadi fokus peneliti (Hikmawati, 2018).

Teknik pengumpulan data dalam penelitian ini dengan menggunakan metode observasi, wawancara dan dokumentasi. Observasi yang peneliti gunakan dalam penelitian ini yaitu observasi langsung dengan mengamati fakta-fakta yang ada. Cartwright \& Cartwright dalam (Herdiansyah, 2014) mendefinisikan sebagai suatu proses melihat, mengamati dan mencermati serta "merekam" perilaku secara sistematis untuk suatu tujuan tertentu. Observasi ialah suatu kegiatan mencari data yang dapat digunakan untuk memberikan suatu kesimpulan atau diagnosis. Wawancara peneliti lakukan untuk memperoleh dan mengumpulkan data dari informan penelitian secara terperinci. Menurut Moloeng (2005) dalam (Herdiansyah, 2014) wawancara adalah percakapan dengan maksud tertentu. Percakapan dilakukan oleh dua pihak yaitu pewawancara (interviewer) yang mengajukan pertanyaan dan terwawancara (interviewee) yang memberikan jawaban atas pertanyaan tersebut. Dokumentasi peneliti gunakan untuk mengumpulkan data-data yang bersifat dokumen seperti data-data sekolah, data-data guru, data-data santri, dan lain-lain.

Teknik analisis data dalam penelitian ini dilakukan dengan reduksi data (data reduction), penyajian data (data display), dan verifikasi (conclusion/drawing). Mereduksi data ialah merangkum, memilih hal-hal yang pokok, memfokuskan pada hal-hal yang penting, dicari tema dan polanya. Dengan mendisplay data, maka akan memudahkan untuk memahami apa yang terjadi, merencanakan kerja selanjutnya berdasarkan apa yang telah dipahami tersebut. Dalam verifikasi data, kesimpulan awal dalam penelitian kualitatif bersifat sementara sapai didikung oleh bukti-bukti yang valid dan konsisten, barulah kesimpulan tersebut menjadi kesimpulan kredibel (Sugiyono, 2012). Teknik yang digunakan dalam pengecekan keabsahan data adalah dengan teknik triangulasi. Dalam penelitian ini, peneliti menggunakan triangulasi teknik dan triangulasi sumber. Triangulasi teknik adalah peneliti menggunakan teknik pengumpulan data yang berbeda-beda untuk mendapatkan data dari sumber yang sama. Sedangkan Triangulasi sumber adalah untuk mendapatkan data dari sumber yang berbedabeda dengan teknik yang sama (Sugiyono, 2012).

\section{Hasil dan Pembahasan}

Adapun perbandingan penelitian ini dengan penelitian terdahulu dari segi hasil penelitian yang dilakukan yaitu: pertama, skripsi yang ditulis oleh Rahmat Ramadhan (2017) yang berjudul pembaharuan pendidikan Islam di pondok pesantren al-Muhsin Purwosari, Kota Metro Lampung. Dari permasalahan yang terjadi, pondok pesantren al-Muhsin Purwosari, Kota Metro Lampung melakukan pembaharuan pendidikan Islam dalam aspek pembaharuan metode belajar, pembaharuan evaluasi, dan pembaharuan organisasi dan manajemen. Kedua, skripsi yang ditulis oleh Adib Muzakky (2020) dengan judul strategi pembaharuan pendidikan Islam di pondok Tarbiyatul Islam al-Falah, Keluruhan Dukuh, Kecamatan Sidomukti, Kota Salatiga. Yang mejadi latar belakang dari pembahararuan pendidikan Islam di pondok Tarbiyatul Islam al-Falah, Keluruhan Dukuh, Kecamatan Sidomukti, Kota Salatiga yaitu perkembangan zaman, sehingga strategi pondok Tarbiyatul Islam al-Falah, Keluruhan Dukuh, Kecamatan Sidomukti, Kota Salatiga dalam pembaharuan pendidikan Islam dengan meninjau tiga aspek, yaitu aspek keterampilan, kerjasama dan kelembagaan. Dan ketiga, jurnal yang ditulis oleh Rengga Satria (2019) dengan judul pembaharuan pendidikan Islam di Madrasah Tarbiyah Islamiyah Canduang. Perbedaan penelitian terletak pada aspek yang diteliti, penelitian terdahulu yang diteliti yaitu aspek kelembagaan, kurikulum pendidikan, pembaruan 
metodologi dan sistem pendidikan, sedangkan aspek yang diteliti dalam penelitian ini yaitu bidang kurikulum.

\section{A. Dinamika Pesantren di Sumatera Barat}

Sumatera Barat merupakan daerah yang ada di Indonesia, yang lebih dikenal dengan sebutan Ranah Minang. Daerah tersebut banyak melahirkan ulama baik dalam tingkat nasional maupun internasional. Sumatera Barat juga memiliki budaya yang berfalsafahkan "adat basandi syara', syara' basandi kitabullah, syara' mangato adat mamakai" (adat berdasarkan kepada hukum, hukum berdasarkan kepada Al-Qur'an, hukum menetapkan, adat yang menerapkan). Filosofi ini menunjukan begitu besarnya peranan agama dan adat dalam menentukan serta mengatur tatanan kehidupan masyarakat Minangkabau. Bagi masyarakat Minangkabau, identitas dan kredibilitas seseorang akan ditentukan bagaimana orang tersebut beragama dan dan beradat dengan baik lembaga yang berfungsi untuk mengembangkan nilai-nilai moral agama dan budaya di Minangkabau adalah surau. Dari suraulah cikal bakal keutuhan dalam masyarakat Minangkabau beradat dan beragama dijalankan secara bersamaan (Yusutria \& Febriana, 2018).

Surau sebagai lembaga pendidikan Islam tradisional di Minangkabau pertama kali didirikan oleh Syaikh Burhanuddin (1066-1111 H/ 1646-1591 M) di Ulakan. Di surau inilah Syaikh Burhanuddin melakukan pengajaran Islam dan mendidik beberapa murid yang menjadi ulama yang berperan penting dalam pengembangan ajaran Islam di Minangkabau. Pendidikan Islam yang dijalankan di surau memiliki karakteristik pendidikan yang sama dengan lembaga pesantren yang dikenal di Jawa (Satria, 2019c). Dari suraulah cikal bakal keutuhan dan keutamaan masyarakat Minangkabau beradat dan beragama dijalankan secara bersamaan. Di surau, diajarkan berbagai pengetahuan seperti pengetahuan agama, ilmu silat, kebudayaan atau adat istiadat, dan juga ilmu politik. Pada tahap ini belum dikenal adanya pembagian kelas dalam belajar, yang menjadi tujuan pokok pengajaran adalah agar pakiah dapat memahami agama Islam dengan benar dan menerapkannya dalam kehidupan sehari-hari.(Yusutria \& Febriana, 2018).

Sejalan dengan keberhasilan perkembangan surau menjadi lembaga pendidikan Islam pertama di Minangkabau, lembaga pendidikan Islam di Minangkabau mengalami modernisasi. Pergesekan modernisasi Islam terjadi antara kaum muda dan kaum tua. Kaum muda. Gerakan modernisasi Islam yang dimulai pada tahun 1900-an ini menjadikan ulama di Minangkabau menjadi dua faksi yang saling bergejolak. Pertama, Faksi Ulama Kaum Tua. Mereka adalah ulama tradisional yang ingin mempertahankan corak Islam sufistik melalui otoritas surau. Kedua, Faksi Ulama Kaum Muda. Mereka adalah murid-murid Syaikh Ahmad Khatib AlMinangkabawi yang melakukan gerakan modernisasi di Minangkabau dengan tujuan menggugat otoritas surau dan corak Islam sufistik dan pengamalan taqlid terhadap imam mazhab (Satria, 2019a).

Munculnya pergolakan agama di awal abad 20 Masehi ini membuat masing-masing kelompok memperdalam hujjahnya, sehingga kitab-kitab berkembang dan diskusi-diskusi sering dilakukan. Para ulama dari dua kelompok ini juga mempertahankan pendirian masingmasing dalam karya-karya yang banyak, baik berupa buku maupun majalah. Kontestasi kaum tua dan kaum muda ini tidak hanya terbatas kepada pemahaman keagamaan. Kontestasi juga terjadi dalam pembentukan organisasi dan dalam aspek pembentukan lembaga pendidikan. Minangkabau merupakan wilayah pertama di Hindia Belanda yang menjadi tempat bagi sekolah-sekolah modern (Satria, 2019a).

Pada tahun-tahun berikutnya, madrasah-madrasah yang berciri modern bermunculan di Minangkabau. Selain madrasah, kaum muda juga mengadopsi surau-surau dengan sistem pendidikan madrasah. Sebagaimana yang dilakukan oleh haji rasul dengan Surau Jembatan Besi di Padang Panjang dan Syaikh Ibrahim Musa dengan Surau Parabek. Pada tahun 1919, surau-surau ulama kaum muda yang bertransformasi menjadi madrasah ini menggabungkan diri dalam sebuah oragnisasi yang diberi nama Sumatera Thawalib. Dan organisasi-organisasi lain menggabungkan diri ke dalam Sumatera Thawalib ini. Sehingga pada masa itu Sumatera Thawalib menjadi oganisasi terkemuka di wilayah Minangkabau. Selain itu, Muhammadiyah juga mendirikan sekolah-sekolah umum yang diminati di Minangkabau. Melihat usaha yang dilakukan kaum muda, kaum tua juga melakukan hal yang sama. Ulama kaum tua mengawali langkah modernisasi pendidikan dengan suatu gerakan yang bermula di Candung. Dan mereka 
akhirnya melakukan pembaharuan pendidikan dari surau menjadi madrasah. Surau hanya menjadi tempat belajar Al-Qur'an, tempat sholat dan tidak ada bedanya dengan musala-musala ditempat lain (Satria, 2019a).

Lembaga pendidikan Islam tradisional yang bersifat lokal semacam pondok, pesantren, dayah, dan surau seakan tidak bisa berkutik ketika berhadapan dengan gelombang modernisasi pendidikan Islam ini. Kemunduran ketika berhadapan dengan model pendidikan barat yang diperkenalkan oleh kolonial Inggris. Dalam konteks Minangkabau, Madrasah lahir dari "pergolakan Agama" meminjam istilahnya Schrieke antara ulama kaum tua dan ulama kaum muda. Madrasah-madrasah yang didirikan oleh ulama kaum muda di wilayah Minangkabau periode 1900-1930 adalah: Adabiyah School, Madrasah School (Sekolah Agama), Madrasah Diniyah, Sumatera Thawalib, dan Madrasah Diniyah Putri. Sedangkan madrasah yang didirikan oleh ulama kaum tua pada periode 1900-1930 adalah Arabiyah School, dan Madrasah Tarbiyah Islamiyah (Satria, 2019a).

\section{B. Pembaharuan Kurikulum di Pondok Pesantren al-Irsyad Islamic Boarding School Bulaan} Kamba, Kubang Putiah (2011-2021)

Berdasarkan penelitian yang telah dilakukan, latar belakang pembaharuan pendidikan di pondok pesantren al-Irsyad Islamic Boarding School Bulaan Kamba diantaranya perkembangan zaman. Azyumardi Azra mengungkapkan bahwa modernisasi atau pembaharuan Islam merupakan upaya untuk menjadikan ajaran Islam agar sesuai dengan perkembangan zaman, artinya ajaran Islam dapat disesuaikan dengan tuntutan sosial sehingga kebiasaan serta pemikiran lama dapat disesuaikan dengan perkembangan zaman dan tidak merubah ajaran Islam yang diajarkan oleh Rasulullah. Modernisasi atau pembaharuan kelembagaan Islam merupakan persyaratan bagi kebangkitan kaum muslimin dimasa modern, mempertahankan pemikiran kelembagaan Islam "tradisional". Adanya pembaharuan kurikulum juga dilatarbelakangi oleh keinginan pondok pesantren untuk maju dan menghasilkan lulusan yang berkualitas. Ini sesuai dengan Permendikbud no. 20 tahun 2003 tentang Standar Pendidikan Nasional pasal 3, yang menyatakan bahwa "pendidikan nasional berfungsi mengembangkan kemampuan dan membentuk dan membentuk watak serta peradaban bangsa yang bermatabat dalam rangka mencerdaskan kehidupan bangsa, bertujuan untuk berkembangnya potensi peserta didik agar menjadi manusia yang beriman dan bertaqwa kepada Tuhan Yang Maha Esa, berakhlak mulia, sehat, berilmu, cakap, kreatif, mandiri, dan menjadi warga negara yang demokratis serta bertanggung jawab (Permendikbud, 2003). Yang melatarbelakangi pembaharuan kurikulum di pondok pesantren al-Irsyad Islamic Boarding School Bulaan Kamba, dengan pelaksanaan tiga kurikulum (kurikulum dinas, kurikulum madrasah dan kurikulum pondok), pembelajaran santri terlalu padat sehingga waktu santri tidak mencukupi.

Bentuk pembaharuan pendidikam Islam di pondok pesantren al-Irsyad Islamic Boarding School Bulaan Kamba Kubang Putiah diantaranya dengan pengintegrasian kurikulum madrasah dengan kurikulum pondok. Pengintegrasian kurikulum sejalan dengan pendapat Djamas (2009), bahwa bentuk integrasi kurikulum dalam kegiatan pembelajaran dapat berupa perpaduan beberapa pokok bahasan dalam suatu tema terentu. Sehingga diharapkan siswa lebih memiliki kedalaman wawasan materi dengan tingkat keterampilan dan pengetahuan yang beragam dan kompleks (multiple knowledge) serta tidak terpecah-pecah sehingga proses pembelajaran yang terjadi lebih bermakna (Zubaidillah \& Asniah, 2021). Selanjutnya dengan membuat kurikulum khusus pesantren. Siti Nursyamsiyah (2019) dalam jurnalnya mengemukakan bahwa pondok pesantren Mu'adalah Baitul Arqom melakukan berbagai macam cara dalam menghadapi globalisasi salah satunya dengan cara membentuk program pesantren, program pesantren yang dilakukan yaitu program menghafal Al-Qur'an dan program menghafal hadis (Nursyamsiyah, 2019). Sedangkan program yang dilakukan oleh pondok pesantren al-Irsyad Islamic Boarding School Bulaan Kamba yaitu takhasus kaligrafi dan takhasus tahfiz exellent. Dan melaksanakan pembelajaran di sekolah di dalam program asrama. Untuk kurikulum di pondok pesantren al-Irsyad Islamic Boarding School Bulaan Kamba kurikulum dinas dan kurikulum madrasah terdapat dalam Kurikulum Menteri Agama (KMA) nomor 184 tahun 2019 tentang Pedoman Implementasi Kurikulum pada Madrasah. Berikut ini perbandingan struktur kurikulum sebelum diintegrasi dengan setelah diintegrasi.

Tabel 1. Kurikulum sebelum di Integrasi 
Struktur Kurikulum

Pondok Pesantren Al-Irsyad Islamic Boarding School Bulaan Kamba

Tahun Ajaran 2018/2019 dan 2019/2020

\section{A. Struktur Kurikulum MTs}

\begin{tabular}{|c|l|c|c|c|}
\hline \multicolumn{1}{|c|}{ Mata Pelajaran } & \multicolumn{3}{c|}{ Alokasi Waktu Perpekan } \\
\hline NO & \multicolumn{1}{|c|}{ VII } & VIII & IX \\
\hline Kelompok A & & & \\
\hline 1 & Pendidikan Agama Islam & 2 & 2 & 2 \\
\hline & a. Al-Qur'an Haadis & 2 & 2 & 2 \\
\hline & b. Akidah Akhlak & 2 & 2 & 2 \\
\hline & c. Fikih & 2 & 2 & 2 \\
\hline & d. Sejarah Kebudayaan Islam & 3 & 3 & 3 \\
\hline 2 & PPKn & 6 & 6 & 6 \\
\hline 3 & Bahasa Indonesia & 3 & 3 & 3 \\
\hline 4 & Bahasa Arab & 5 & 5 & 5 \\
\hline 5 & Matematika & 5 & 5 & 5 \\
\hline 6 & Ilmu Pengetahuan Alam & 4 & 4 & 4 \\
\hline 7 & Ilmu Pengetahuan Sosial & 4 & 4 & 4 \\
\hline 8 & Bahasa Inggris & & & \\
\hline Kelompok B & 3 & 3 & 3 \\
\hline 1 & Seni Budaya & 3 & 3 & 3 \\
\hline 2 & PJOK & 2 & 2 & 2 \\
\hline 3 & Prakarya dan / atau Informatika & 46 & 46 & 46 \\
\hline 4 & Muatan Lokal & & & \\
\hline & & & & \\
\hline
\end{tabular}

B. Struktur Kurikulum MA

\begin{tabular}{|c|l|c|c|c|}
\hline \multirow{2}{*}{ NO } & \multicolumn{1}{|c|}{ Mata Pelajaran } & \multicolumn{3}{c|}{ Alokasi Waktu Perpekan } \\
\hline Kelompok A (Umum) & X & XI & XII \\
\hline 1 & Pendidikan Agama Islam & & & \\
\hline & a. Al-Qur'an Haadis & 2 & 2 & 2 \\
\hline & b. Akidah Akhlak & 2 & 2 & 2 \\
\hline & c. Fikih & 2 & 2 & 2 \\
\hline & d. Sejarah Kebudayaan Islam & 2 & 2 & 2 \\
\hline 2 & PPKn & 2 & 2 & 2 \\
\hline 3 & Bahasa Indonesia & 4 & 4 & 4 \\
\hline 4 & Bahasa Arab & 4 & 2 & 2 \\
\hline 5 & Matematika & 4 & 4 & 4 \\
\hline
\end{tabular}




\begin{tabular}{|c|c|c|c|c|}
\hline 6 & Sejarah Indonesia & 2 & 2 & 2 \\
\hline 7 & Bahasa Inggris & 3 & 3 & 3 \\
\hline \multicolumn{5}{|c|}{ Kelompok B (Umum) } \\
\hline 1 & Seni Budaya & 2 & 2 & 2 \\
\hline 2 & PJOK & 2 & 2 & 2 \\
\hline 3 & Prakarya dan Kewirausahaan & 2 & 2 & 2 \\
\hline 4 & Muatan Lokal & & & \\
\hline \multicolumn{5}{|c|}{ Kelompok C (Peminatan) } \\
\hline \multicolumn{5}{|c|}{ Peminatan Akademik } \\
\hline 1 & Goegrafi & 3 & 4 & 4 \\
\hline 2 & Sejarah & 3 & 4 & 4 \\
\hline 3 & Sosiologi & 3 & 4 & 4 \\
\hline 4 & Ekonomi & 3 & 4 & 4 \\
\hline \multicolumn{5}{|c|}{ Mata Pelajaran Pilihan: } \\
\hline \multicolumn{2}{|c|}{ Mata Pelajaran Pilihan Lintas Minat dan / atau } & \multirow{2}{*}{6} & \multirow{2}{*}{4} & \multirow{2}{*}{4} \\
\hline \multicolumn{2}{|c|}{ Pendalaman Minat dan / atau Informatika } & & & \\
\hline & Jumlah & 51 & 51 & 51 \\
\hline
\end{tabular}

KURIKULUM PONDOK

TAHUN 2018/2020

\begin{tabular}{|c|l|c|c|c|c|c|c|}
\hline \multirow{2}{*}{ NO } & \multicolumn{2}{|c|}{ Mata } & \multicolumn{6}{c|}{ Kelas } \\
\cline { 2 - 8 } & \multicolumn{1}{|c|}{ Pelajaran } & VII & VIII & IX & X & XI & XII \\
\hline 1 & Fikih & 2 & 2 & 2 & 2 & 3 & 3 \\
\hline 2 & Tauhid & 2 & 2 & 2 & 2 & 2 & 2 \\
\hline 3 & Hadist & 2 & 2 & 2 & 2 & 2 & 2 \\
\hline 4 & Ilmu Hadist & & & & 2 & 2 & 2 \\
\hline 5 & Tafsir & & & & 2 & 2 & 2 \\
\hline 6 & Ilmu Tafsir & & & & 2 & 2 & 2 \\
\hline 7 & Usul Fikih & 2 & 2 & 2 & 2 & 2 & 2 \\
\hline 8 & Nahwu & 2 & 2 & 2 & 2 & 2 & 2 \\
\hline 9 & Sharaf & 4 & 4 & 4 & 3 & 2 & 2 \\
\hline 10 & Balagah & 2 & & & & & \\
\hline 11 & Tahfizh & 1 & 1 & 1 & & & \\
\hline 12 & Muhadasah & $\mathbf{1 7}$ & $\mathbf{1 5}$ & $\mathbf{1 5}$ & $\mathbf{2 1}$ & $\mathbf{2 2}$ & $\mathbf{2 3}$ \\
\hline 13 & BK & $\mathbf{6 3}$ & $\mathbf{6 2}$ & $\mathbf{6 2}$ & $\mathbf{7 2}$ & $\mathbf{7 3}$ & $\mathbf{7 4}$ \\
\hline & Jumlah & & & & 1 & 2 \\
\hline & TOTAL & & & 2 & 2 \\
\hline
\end{tabular}

(Sumber: Waka kurikulum pondok pesantren al-Irsyad Islamic Boarding School Bulaan Kamba)

Tabel 2. Kurikulum setelah di Integrasi 
Struktur Kurikulum

Pondok Pesantren Al-Irsyad Islamic Boarding School

Bulaan Kamba

Tahun Ajaran 2020/2021

A. Mata Pelajaran Umum dan Madrasah

\begin{tabular}{|c|l|c|c|c|c|c|c|}
\hline \multirow{2}{*}{ NO } & \multirow{2}{*}{ Mata Pelajaran } & \multicolumn{7}{c|}{ Kelas } \\
\cline { 3 - 8 } & & VII & VIII & IX & X & XI & XII \\
\hline 1 & Al-Quran Hadis & 2 & 2 & 2 & & & \\
\hline 2 & Fikih & 2 & & & & & \\
\hline 3 & SKI & 2 & 2 & 2 & & & \\
\hline 4 & Akidah Akhlak & 2 & 2 & 2 & & & \\
\hline 5 & B.Arab & 2 & 3 & 3 & 4 & 2 & 2 \\
\hline 6 & Matematika & 4 & 4 & 4 & 4 & 4 & 4 \\
\hline 7 & B.Inggris & 3 & 4 & 4 & 3 & 3 & 3 \\
\hline 8 & B.Indonesia & 4 & 4 & 4 & 3 & 3 & 3 \\
\hline 9 & IPA & 4 & 4 & 4 & & & \\
\hline 10 & PKN & 2 & 2 & 2 & 2 & 2 & 2 \\
\hline 11 & IPS & 3 & 3 & 4 & & & \\
\hline 12 & Penjas & 2 & 2 & 2 & 2 & 2 & 2 \\
\hline 13 & SBDY & & & & & & \\
\hline 14 & Prakarya & 2 & 2 & 2 & & & \\
\hline 15 & Geografi & & & & 3 & 3 & 3 \\
\hline 16 & Sosiologi & & & & 3 & 3 & 3 \\
\hline 17 & Ekonomi & & & & 3 & 3 & 3 \\
\hline 18 & Sejarah Peminatan & & & & 2 & 2 & 2 \\
\hline 19 & Sejarah Indonesia & & 1 & 1 & & & \\
\hline 20 & BK & & & 2 & 2 & 2 \\
\hline
\end{tabular}

B. Mata Pelajaran Pondok

\begin{tabular}{|c|c|c|c|c|c|c|c|}
\hline \multirow{2}{*}{ NO } & \multirow{2}{*}{$\begin{array}{c}\text { Mata } \\
\text { Pelajaran }\end{array}$} & \multicolumn{6}{|c|}{ Kelas } \\
\hline & & VII & VIII & IX & $\mathbf{X}$ & XI & XII \\
\hline 21 & Fikih & 2 & 3 & 3 & 3 & 4 & 3 \\
\hline 22 & Nahwu & 3 & 4 & 3 & 2 & 2 & 2 \\
\hline 23 & Sharaf & 3 & 3 & 3 & 2 & 2 & 2 \\
\hline 24 & Tauhid & 2 & 2 & 2 & 2 & 2 & 2 \\
\hline 25 & Hadist & 2 & 2 & 2 & 2 & 2 & 2 \\
\hline 26 & Ilmu Hadist & & & & 2 & 2 & 2 \\
\hline 27 & Tafsir & & & & 2 & 2 & 2 \\
\hline 28 & Ilmu Tafsir & & & & 2 & 2 & 2 \\
\hline 29 & Usul Fikih & & & & 2 & 2 & 2 \\
\hline 30 & Balagah & & & & & 1 & 2 \\
\hline
\end{tabular}




\begin{tabular}{|c|l|c|c|c|c|c|c|}
31 & Tahfizh & 4 & 4 & 4 & 3 & 3 & 3 \\
\hline 32 & Muhadasah & 2 & & & & & \\
\hline & Jumlah & $\mathbf{5 3}$ & $\mathbf{5 3}$ & $\mathbf{5 3}$ & $\mathbf{5 3}$ & $\mathbf{5 3}$ & $\mathbf{5 3}$ \\
\hline
\end{tabular}

(Sumber: Waka kurikulum pondok pesantren al-Irsyad Islamic Boarding School Bulaan Kamba)

Berdasarkan tabel 1 dan 2 di atas jelas terlihat bahwa beban jam pelajaran pada tabel 1 sangat padat dengan jumlah beban pelajaran santri untuk tingkat Mts, 61-63 jam pelajaran perminggu, sedangkan untuk tingkat MA, 72-74 jam perminggu. Setelah dilakukan integrasi kurikulum beban pelajaran tingkat MTs dan tingkat MA menjadi 53 jam perminggu.

\section{Pembaharuan Pengkajian Kitab Kuning di Pondok Pesantren al-Irsyad Islamic Boarding School Bulaan Kamba, Kubang Putiah}

Kitab kuning merupakan salah satu ciri utama pembeda antara pesantren dengan lembaga pendidikan lainnya. Sebagaimana Hasbullah (1995) mengungkapkan bahwa kitab klasik atau yang lebih dikenal dengan kitab kuning adalah unsur pokok yang cukup membedakan pesantren dengan lembaga pendidikan lainnya. Kitab kuning ialah kitab klasik Islam yang dirulis dengan bahasa Arab baik yang ditulis tokoh muslim Arab maupun para pemikir ulamaulama Islam (Hasbullah, 1995). Disebut kitab kuning karena pada umumnya kitab-kitab tersebut dicetak di atas kertas berwarna kuning, berkualitas rendah, dan kadang-kadang lembarannya lepas tidak terjilid sehingga mudah diambil bagian-bagian yang diperlukan tanpa harus membawa satu kitab secara utuh. Biasanya, para santri hanya membawa lembaranlembaran tertentu yang akan dipelajari. Karena bentuk hurufnya yang gundul, kitab ini tidak mudah dibaca apalagi dipahami oleh yang tidak memahami gramatika bahasa Arab, nahwu dan sharaf (Daulay, 2007). Tradisi pesantren seperti kajian kitab kuning ini haruslah mengalami kontekstualisasi baik dari segi metodologi pembelajarannya maupun dari segi paradigmatik. Hal ini dilakukan agar kajian kitab kuning tetap memiliki relevansi dengan persoalan umat yang semakin kompleks. Kontekstualisasi kitab kuning adalah langkah penting yang harus diambil (Satria, 2019b).

Dari hasil penelitian, pemakaian sumber belajar kitab kuning dan pelaksanaan pembelajarannya di pondok pesantren al-Irsyad Islamic Boarding School Bulaan Kamba mengalami pembaharuan, terutama mulai terlihat sekitar tahun 2011 sampai saat ini. Pada awalnya pondok pesantren menggunakan kitab kuning sebagai sumber belajar kitab, sekitar tahun 2014 kitab yang digunakan adalah kitab silsilatul lughah terbitan perguruan tinggi dari kota Riyadh, yaitu Universitas Islam Muhammad bin Su'ud. Ada beberapa kitab kuning yang dipakai untuk pembinaan santri di asrama, seperti kitab ta'limul muta'allim dan fighussunnah, ini tidak masuk ke dalam kurikulum pondok, yang masuk pada kurikulum pondok hanya kitab yang dipelajari di sekolah. Pada tahun 2020 sumber belajar santri dalam pembelajaran kitab kembali menggunakan kitab kuning. Namun, guru juga bisa menggunakan silsilatul lughah sebagai pegangan guru. Berbeda dari tahun sebelumnya, semua kitab yang dipakai untuk pembelajaran masuk ke dalam kurikulum pondok.

Berikut ini mata pelajaran kitab yang dipelajari di pondok pesantren al-Irsyad Bulaan Kamba. Untuk tingkat MTs terdiri dari tauhid, nahwu, saraf, fiqih, dan hadis. Sedangkan untuk tingkat MA terdiri dari tauhid, nahwu, sharaf, fiqih, hadits, ilmu hadits, tafsir, ilmu tafsir, ushul fiqh, dan balaghah. Dan untuk kitab belajar sebagaimana tertera dalam tabel 3 berikut:

Tabel 3. Kitab sumber belajar pondok pesantren al-Irsyad Bulaan Kamba

\begin{tabular}{|c|c|l|l|l|}
\hline \multirow{2}{*}{ No } & \multicolumn{2}{|c|}{ Tingkat MTs } & \multicolumn{1}{c|}{ Ningkat MA } \\
\cline { 2 - 5 } & Mapel & \multicolumn{1}{|c|}{ Nama Kitab } & Mapel & \multicolumn{1}{c|}{ Nama Kitab } \\
\hline 1 & Tauhid & Al-jawahirul kalamiyah & Tauhid & Al-husunulhamidiyyah \\
\hline 2 & Nahwu & $\begin{array}{l}\text { Mukhtasar jiddan, Mattan } \\
\text { al-'ajrumiyya, Amtsilah } \\
\text { at-tashrifiyyah }\end{array}$ & Nahwu & $\begin{array}{l}\text { Mulakhas qawa'idullughah al- } \\
\text { 'arabiyyah }\end{array}$ \\
\hline 3 & Sharaf & Matan bina wal-asas & Sharaf & $\begin{array}{l}\text { Mulakhas qawa'idullughah al- } \\
\text { 'arabiyyah }\end{array}$ \\
\hline
\end{tabular}




\begin{tabular}{|c|c|c|c|c|}
\hline 4 & Fiqih & Fiqhulwadih & Fiqih & Fiqhussunnnah \\
\hline 5 & Hadits & $\begin{array}{l}\text { Silsilah ta'limul lughah al- } \\
\text { 'arabiyyah: al-hadits }\end{array}$ & Hadist & $\begin{array}{l}\text { Bulughulmaram, } \\
\text { Subulussalam }\end{array}$ \\
\hline 6 & & & $\begin{array}{l}\text { Ilmu } \\
\text { Hadits }\end{array}$ & Taytsir mushtalahul hadits \\
\hline 7 & & & Tafsir & $\begin{array}{l}\text { Shafwatut-tafatsir, Tafsir } \\
\text { jalalain }\end{array}$ \\
\hline 8 & & & $\begin{array}{l}\text { Ilmu } \\
\text { Tafsir }\end{array}$ & $\begin{array}{l}\text { Mana'ul qathan, Mabahats fil' } \\
\text { ulimul qur'an }\end{array}$ \\
\hline 9 & & & $\begin{array}{l}\text { Ushul } \\
\text { Fiqih }\end{array}$ & Assullam \\
\hline 10 & & & Balaghah & $\begin{array}{l}\text { Silsilah ta'limul lughah } \\
\text { al'arabiyyah: Balaghatun } \\
\text { naqdu }\end{array}$ \\
\hline
\end{tabular}

Untuk pelaksanaan pembelajaran kitab di pondok pesantren pesantren al-Irsyad Islamic Boarding School Bulaan Kamba, Kubang Putiah pada tahun sebelum tahun 2014, pemakaian kitab sebagai sumber belajar dengan metode ceramah, guru menjelaskan di depan dan santri menyimak penjelasan dari guru, kemudian setelah dijelaskan santri akan diminta untuk membacakan dan menerjemahkan pembelajaran yang telah dipelajari, baik pada pertemuan hari itu maupun pertemuan sebelum-sebelumnya. Ketika tahun 2015-2019 kitab yang dipakai sebagai sumber belajar dominan memakai kitab silsilatul lughah. Metode belajar santri berbeda dari sebelumnya. Walaupun di awal pembelajaran guru tetap menjelaskan, akan tetapi santri memakai metode latihan, karena pada kitab tersebut tersedia latihan-latihan. Dan mulai dari tahun 2020, pondok pesantren al-Irsyad Islamic Boarding School Bulaan Kamba, Kubang Putiah kembali memakai dominan kitab kuning sebagai kitab pembelajaran. Pada pembelajaran kali ini guru juga boleh memakai kitab silsilatul luqhah untuk mengasah kemampuan santri. Karena pada kitab kuning tidak terdapat latihan-latihannya. Guru juga lebih kreatif dalam pembelajaran dengan metode mind maping, peta konsep, dan lain-lain sehingga pembelajaran lebih menarik dan tidak monoton.

\section{Kesimpulan}

Pembaharuan kurikulum di pondok pesantren al-Irsyad Islamic Boarding School Bulaan Kamba, Kubang Putiah, dengan pengintegrasian (menggabungkan) kurikulum madrasah dengan kurikulum pondok dan merumuskan kurikulum kekhasan pondok pesantren. Pembaharuan dilatarbelakangi oleh beberapa faktor, diantaranya; perkembangan dan tuntutan zaman dalam dunia pendidikan; kurikulum (kurikulum pondok) harus disesuaikan dengan visi dan misi yang dirumuskan pesantren; dengan beban/jam pelajaran terlalu padat, sehinga waktu pembelajaran tidak mencukupi; guru memiliki potensi dalam mengajar mata pelajaran yang diintegrasikan; hasil santri yang kurang memuaskan; dan tentunya pondok pesantren ingin mencapai kualitas yang lebih baik. Pembaharuan kurikulum yang terlaksana di pondok pesantren berjalan dengan baik.

Pemakaian sumber belajar kitab kuning dan pelaksanaan pembelajaran di pondok pesantren al-Irsyad Islamic Boarding School Bulaan Kamba juga mengalami pembaharuan, terutama mulai terlihat sekitar tahun 2011 sampai saat ini. Pada awalnya pondok pesantren menggunakan kitab kuning sebagai sumber belajar kitab, sekitar tahun 2015 kitab yang digunakan adalah kitab silsilatul lughah terbitan perguruan tinggi dari kota Riyadh, yaitu univeritas Islam Muhammad bin Su'ud. Dan pada tahun 2020 sampai sekarang sumber belajar santri dalam pembelajaran kitab kembali menggunakan kitab kuning. Akan tetapi ada juga beberapa pembelajaran yang memakai kitab silsilatul lughah. Pendidik juga bisa menggunakan kitab silsilatul lughah sebagai pegangan dan pedoman dalam belajar. 


\section{Daftar Kepustakaan}

Anwar, A. L. I. (2011). Pembaruan Pendidikan di Pesantren Lirboyo Kediri (II). Pustaka Belajar.

Basyit, A. (2017). Pembaharuan Model Pesantren: Respon terhadap Modernitas. XVI(33), 293-324.

Daulay, H. P. (2007). Sejarah Pertumbuhan \& Pembaharuan Pendidikan Islam di Indonesia. Kencana.

Fuady, A. S. (2020). Pembaharuan Sistem Pendidikan di Pesantren. Al-Insyiroh: Jurnal Studi Keislaman, 6(1), 101-114.

Hasbullah. (1995). Sejarah Pendidikan Islam di Indonesia: Lintas Sejarah Pertumbuhan dan Perkembangan. Raja Grafindo Persada.

Herdiansyah, H. (2014). Metodologi Penelitian Kualitatif untuk Ilmu-ilmu Sosial. Salemba Humanika.

Hikmawati, F. (2018). Metodologi Penelitian. Rajagrafindo Persada.

Narbuko, C., \& Achmadi, A. (2003). Metodologi Penelitian. Bumi Aksara.

Nursyamsiyah, S. (2019). Penguatan Sistem Pendidikan Pondok Pesantren Mu'adalah di Era Globalisasi (Studi Kasus Pondok Pesantren Modern Baitul Arqom Balung Kabupaten Jember). 2(1), 21-34.

Permendikbud. (2003). Permendikbud Nomor 20 Tahun 2003 tentang Sistem Pendidikan Nasional.

Rifai, A. S. (2017). Pembaharuan Pendidikan Pesantren dalam Menghadapi Tantangan dan Hambatan di Masa Modern. Jurnal Inspirasi, 1(1), 21-38.

Satria, R. (2019a). Dari Surau ke Madrasah : Modernisasi Pendidikan Islam di Minangkabau. Tadris: Jurnal Pendidikan Islam, 14. https://doi.org/10.19105/tjpi.

Satria, R. (2019b). Intelektual Pesantren: Mempertahankan Tradisi di Tengah Modernitas. Turast: Jurnal Penelitian Dan Pengabdian, 7(2), 177-194. https://ejournal.uinib.ac.id/jurnal/index.php/turast/article/view/1301

Satria, R. (2019c). Pembaruan Pendidikan Islam di Madrasah Tarbiyah Islamiyah Canduang. Jurnal Pendidikan Agama Islam, 6(1), 15-22.

Sugiyono. (2012). Metode Penelitian Kuantitatif, Kualitatif dan R\&D. Alfabeta.

Yusutria, \& Febriana, R. (2018). Robohnya Lembaga Pendidikan Surau. Jurnal Kependidikan Dan Keagamaan, 2.

Zubaidillah, M. H., \& Asniah. (2021). Integrasi Kurikulum Pondok dan Negeri di Madrasah Aliyah Normal Islam Putera Rasyidiyah Khalidiyah Amuntai. Prosiding Konferensi Integrasi Interkoneksi Islam Dan Sains, 3, 93-96. http://sunankalijaga.org/prosiding/index.php/kiiis/article/view/714 